\title{
The Contribution of Prenatal Psychology to Our Understanding about Prenatal Dynamics and Fetal Behaviour
}

\author{
Olga Gouni \\ National and Kapodistrian \\ University of Athens, \\ Athens, Greece
}

\author{
Slobodan Sekulic \\ University of Novi Sad, \\ Novi Sad, Serbia
}

\author{
Anastasia Topalidou \\ University of Central Lancashire, \\ Preston, UK
}

\begin{abstract}
Research in the prenatal human experience has very clearly shown that whatever mother experiences all her life until conception and even more impactfully during conception and pregnancy passes down to the child she is pregnant with. Modern Biology has shown that environmental information and the perception that governs this environment gets encoded in the cell consciousness. A simple thought or act can upset or stabilize the whole planet or... fetal existence. Subtle differences in the motivation of our choices may have the power to bring about radically different conditions in the process of events. A simple thought of fear can lead to a trauma, a disease, a holocaust while a simple thought of compassion can take humanity out of the platonic cave into the healing light of creation. Is there anything we can do? Can we learn from what we already know about prenatal dynamics and move on to design and implement salutogenic processes for the benefit of all involved? The paper will attempt to show the most important findings about prenatal dynamics and fetal existence and how they are connected with our postnatal health and wellbeing from the times of Freud and especially his students who took psychoanalysis from the childhood to birth experience and then to pregnancy and conception and beyond.
\end{abstract}

Keywords: prenatal imprinting, postnatal health, fetal programming, bonding, maternal environment, non-genetic influences

\section{Introduction}

During my two full decades of my clinical work with people from all ages and all walks of life, not restricted to Greece or Cyprus but also to other continents have allowed me to delve into the depths of the human experience and stay aghast in front of the wisdom that is revealed in front of my eyes as plain people uncover the hidden origins of their challenges and at the same time the prenatal-sometimes

\footnotetext{
*Acknowledgements: This work was supported and funded by COST Action IS1405, Building Intrapartum Research Through Health - an interdisciplinary whole system approach to understanding and contextualising physiological labour and birth (BIRTH). Gratitude: I am grateful to all those that have stepped into my practice room for their trust and allowing me to share their treasures with me, expanding my consciousness every single day. And, I am grateful to all of you who have been my inspirers and teachers. A special thank you to Whole-Self Psychology, Philosophy and Education for opening vast avenues of wisdom and surrounding me with friendship and love. I am also very grateful to all friends for understanding the significance of this knowledge for the midwives and all those present during pregnancy, birth and beyond as this can be a transformation tool leading to Peace, Health and Wellbeing for the Humanity.

Olga Gouni, BA, PPC, Cosmoanelixis, Prenatal \& Life Sciences, National and Kapodistrian University of Athens.

Slobodan Sekulic, MD, Ph.D., Department of Neurology, Faculty of Medicine, University of Novi Sad.

Anastasia Topalidou, Ph.D., Allied Health Research Unit, School of Health Sciences, University of Central Lancashire.
} 
preconception - dynamics of their experience.

From my clinical work, I have chosen to use some of my countless case stories to share with you the significance of the primal experience for the postnatal life of all of us.

Today, midwives, obstetricians, clinicians and academics who explore and work with pre/Perinatal dynamics play a most precious role in the evolution of human race. Especially those who are also present during pregnancy and birth are called to offer more than just a safe natural passage from the unborn state of being to the being born one - for the baby - and the support to the birthing mother. Their role has expanded a lot, especially for midwives. Now, a midwife is the first person a pregnant woman will go to and ask for support and guidance. Due to the change in the family dynamics, pregnant parents are not initiated and supported by their own parents or the knowledgeable, wise figures of the tribe or the local society. Pregnant parents seek primal wisdom in pregnancy groups, "get-ready-to birth" gatherings and the such, mostly facilitated by midwives and/or psychologists specialized in the field. Thus, midwives need to explore and delve into the truths of other scientific fields and use this knowledge to better understand and better serve. Prenatal Psychology is one of these fields. Prenatal Psychology has a lot of treasures for her to get and use especially in Primal Health Advancement Programs to work with the baby conceived, gestated and being born.

\section{What Is Prenatal Psychology?}

Today, with the term "Prenatal Psychology", we refer to the Psychology Approach that studies the prenatal and Perinatal Dynamics of a Human Being from even before conception to the time of weaning - some 3 years after birth - and finds the origins of whatever health or dysfunction a human being deals with in his postnatal life as a child, adolescent or adult in his primal experiences.

It is a specialty that came from the Freudian Psychoanalysis, which-at its time late 19th, 20th century - revolutionized the way we looked at human behavior. Due to the significant contributions of Freud's students such as Otto Rank and Sandor Ferenczi who first spoke of the birth trauma and the ways it shows again in our living experience, e.g., phobias, sex dysfunction, sleep disorders, etc., the frontiers to our understanding human dynamics were pushed beyond our childhood which was the research area of classical psychoanalysis. More significant contributions were offered by Wilhelm Reich and Carl Jung —also Freud's students at the time - who cast even more light on the somatic aspects and the dream/archetype symbolism. Depth analysis became even deeper. Early 1920s and 1930s was a very active time in what led to what now know as Prenatal Psychology: Nador Fodor \& Francis Mott (the umbilical affect) took it even further-or better say even deeper - and spoke about how pregnancy can shape postnatal life actually becoming the Fathers of Prenatal Psychology. The next 2 generations of theoreticians and clinicians that followed in their steps gave us insights that make the "unknown" a known scene. Today, the torch bearing generation explores the depths of the depths, that is conception dynamics as this seems to be the most critical moment connected with the quality of life we experience as individuals and as Humanity. The field is most interesting, holding the keys to a better understanding of who we are and what is behind who we become.

\section{What We Know}

During more than 100 years of observation, study and research these, are some of the most important findings we now know.

\section{We Exist Long Before We Are Born}

The way we are conceived, gestated and born is critical for who we become as it is the initial template for 
the rest of our life. There is a "center" in each one of us that registers all information in this primal experience and beyond. Peerbolte called it "genius", "the Third Factor" the bridge between id and ego, others called it consciousness, and The Turners call it Whole-Self. This center of intelligence becomes aware of life data, emotions, feelings, thoughts or other imprints that refer to the experience of either/both parents.

The Embryologist Jaap van der Waal in his paper "The Speech of the Embryo" makes the following most interesting observations and expands our understanding even more including elements like time, form, gesture, shape etc in the effort of the organism to express his essence: He says:

The embryo may be considered as a continuous whole or complete self-organized being that seems to fall apart into its bodily constituents and organs. The actual embryo is maintaining order or centering this process... Like every living being, the human embryo is in every phase of development a coherent whole, a unity of form, shape and function interacting with its environment. It is always itself... From conception till birth, from birth till death, the human biography is an organic entity, wholeness.

In all these processes of embryonic development, DNA or genes do not play the causal or determining role... (The genome) is regulated and determined continuously as a process in time by the context and environment of that genome, i.e., the position of the cell within the whole of the embryo.

The embryo continuously changes its apparent shape as a steady metamorphosis of form... Differentiation goes from outside to inside as well, not just from inside (the parts) to outside (the whole).

\section{Shared Experiences: The Contact and the Contract}

Whatever the maternal environment experiences is experienced by the unborn baby at the same time, no delays. Any charged events during pregnancy are recorded by the baby and may add to the traumata or relieve certain stress. One of the most crucial experiences are rejection: either total rejection of existence or partial rejection of identity, e.g., sex preference, loss of beloved, violence, not responding to the primal needs of the baby in gestation, isolation. Nijhout (1990) said, "Environmental signals control the switching on and off of genes". And, Thaler (1994) said "Organisms under stress are able to actively alter their DNA and create new genes in an effort to accommodate environmental challenges".

When a pregnant woman experiences an event, she can be reacting in a positive, enhancing way (joy, calmness, satisfaction, pleasure, security, etc.) or she can be reacting in a negative, diminishing way with depression, fear, terror and panic. On the physical level, enhancing emotions can trigger massive rushes of either endorphins of pleasure or trauma can trigger adrenalin and noradrenalin hormones in her blood which are then passed from her body through the placenta to the little body she is growing for her baby. If the messages are endorphin-based hormones, then baby can continue her or his constructive, creative work. If the messages are catecholamine-based hormones because of mother's trauma, baby gets disturbed. As Verny (1981) says "The baby stops the creative and goes to the defensive mode". And as the Turners (1988) explain: "I, the baby, am born with mother's hypnotic trauma trance, non-conscious belief that these events are still happening as well as with the hormonal saturation which causes the accompanying specific sensation throughout my life".

Thus, my in initial prenatal contact becomes a contract activated and re-activated again and again in my life and becomes the structure, the innate core source of my pathological feelings which may then be reinforced by later events.

Frank Lake, William Emerson and other prenatal pioneers have clearly shown that shocks or deep traumas in the 1st trimester can be responsible for the psychoses that torture people in later life, while 3rd trimester traumatic events can be blamed for most "normal" neuroses. 
Let's look at one of the cases:

Marina. Marina, a woman in her late thirties, mother of two girls, had a great difficulty with her female manager. In the first minutes of the session, she complains:

My recognition from others is being threatened. I can't define my job. My manager knows how to push me out of my center. What she wants to tell me is, "You aren't good at what you do!" She is a threat for me. I am angry! I do more than I can to defend myself. I am in despair! I can't stand myself! I feel my mind is exhausted! My mind works so hard that I feel my brain will explode! My mind works incessantly! It is being burnt out!

Marina's prenatal context. Her parents were not married when she was conceived. Her mum, a young lady at the time, fearful of her own father reactions to the news of out-of-marriage pregnancy and fearful of the social stigma has abortion thoughts. Then, when she communicates the news to her partner, he reassures her that they can get married and have the child. When Marina's mother discovered the news of pregnancy, Marina's brain was at a crucial moment of development. The whole stress seems to have concentrated in her brain/head.

\section{Marina's contact.}

The grey creature (the fetal brain) looking with eyes wide open at a dark environment. There is a light on top. It must be at the time when mother was pregnant. This creature must fight to live. It must save itself. Somebody is threatening it. No, it is a thought that is threatening it. This thought is causing it pain. It is that they don't want it. As if someone wants to kill it. I don't feel it's mum. It must be her fear of the other people. Mum also fears for her life. She is afraid that they will beat her; they will hurt her; they will make her feel bitterness. Her fault is that she reacted to what others wanted her to do. She tried to live free. She fell in love; she had sex and now this pregnancy. She is not married; she is young; she is at that age that she is not fully independent and has to tell her parents. She is afraid of her father. This thought/fear that she will be beaten and hurt makes her think of getting rid of this thing, this child. She doesn't want to let it grow because if she does her own shameful act will be seen. People will accuse her of being a whore. She doesn't want that. She didn't make love out of low emotions. She had simply let herself to a man she loved. But she has never learnt how to fight for her rights and her desires. I love you, mum. But, Mum is in her panic. Her mind doesn't listen. Somebody else allowed me to live. Mum must be in such great panic that she doesn't listen inside. It's only when dad reassures her that he will be by her that "We want what has happened to us. We don't care what the other people will say!" that she calms down.

Marina relaxes when her father speaks to her mum and supports her saying: "Our baby needs to grow. It is our baby. It is the seed of our love. We want this baby and we love it". At this, Marina says:

Marina calms down and stretches a little bit. (She was crouched down in fear). There is somebody who thinks of her. Mum is happier. Mum feels safe in the arms of dad. Dad is very strong. There passed many years to realize that dad was sensitive too. I thought that dad was omnipotent. I felt he could be the Prime Minister, a king, a teacher any position of authority. He deserved it. I was wondering why he wasn't in such position.

Some further analysis revealed:

Marina (speaking to her parents):

You will love me but I'll tell you if you love me. Nobody persuades me. I'll test you. I'll stretch you to the limits. I want you to deal with me. It is selfish but I don't know it. Anyway, I didn't ask you to hurt me. You didn't even ask me if I like being hurt. You have never paid any attention to me. You have never cared about me. How do they dare to ask me to respect you? When I experienced that danger (mum wanted to have an abortion) it was your fault. You should not have let me go through that danger. You shouldn't even have thought of abortion. You have to convince me with your deeds that you love me.

\section{Whose Feelings? Whose Perceptions?}

The moment, the maternal environment experiences a stressful situation, the (un)born baby gets the information and this "contact" influences the way the baby sees self, others, the world leading to a "contract" 
that is way the baby will relate to himself, others or the whole world after birth.

The sequence is that every time, through (speaking in the 1st person) my mother's charged emotions and charged thoughts, my environment generates a threatening message, I, the unborn child, although I may be unaware of the scenarios that cause the specific maternal response, am well aware of the physiological consequences and sensations of this response. At that moment, I interrupt the creative work I do and the positive feelings as well as the positive ideas I have of myself. Plus, all the positive conclusions I have had so far in my life all come to an end and my threatened existence will do its best to survive.

At the same time, the way I think of myself gets replaced by sabotaging self-judgments and diminishing decisions. My perception of the world as a safe place changes into images of a threatening place to be, a place I need to do something to protect myself or the ones I care about.

As a result, I either become armoured and adopt a defensive stand (usually by becoming offensive myself) or as is in cases of deep rejection, I make a diminishing decision against myself, boycotting and sabotaging my own existence in every possible way.

\section{Maria's prenatal context.}

During gestation, I felt hungry. Something stopped food from flowing to me. I could see food coming, then it sort of diluted. There was something filthy and ill-smelling. It is not food. It is poison. It is anger. Mum is angry at dad. All this is heavy and difficult. Mum has realized that she will be alone and unsupported in her experience as a parent. She needed more love and affection from father. Father looked at all this as a simple process. Mum feels deserted and unsupported. Many, many siblings of mine have died because of this. I am the only one who survived. Every time, it happened, I said: "Be strong, my brother, please". And I begged for them to stand. And every time they perished.

\section{Maria's contract.}

I died, too. I cancelled my existence. I didn't exist. It is so difficult to exist in life because I need to try hard to sustain life and I need to try even harder to earn some joy in life.

Maria is the only child, conceived after medical support. She has serious sexual difficulties as she has practiced so hard to block all entrances to the inside of her body to protect herself from poison invading her.

Other times, I turn into a prenatal therapist making decisions to support my parents so that they can survive or be emotionally happy—so that I, their child, can share in their peace.

Joan's prenatal context. At the moment of conception, Joan's father-a young man at the time, had lost his father at age 16. He was the sole support for his mother and a younger brother and sisters. In his effort to protect himself from misunderstandings and social criticism and to guarantee that the family barbershop-once run by the father-would continue to provide for all the family, he had adopted a very serious persona.

Joan's contract. As a little girl, Joan used to tease her father and do hairdos. As an older kid, she always followed him in the fields or on bike rides. As a young lady, she would always support him when mother complained. As a young adult, she would never say "No!" to him and his decisions. Joan could sense her father's sorrow and deep loneliness and promised to do whatever she could to cheer him up or protect him from being sad. A contract that she honoured all her life up to now.

\section{Pink and Blue Fantasies}

If the situation is one of rejection of my sex or failure to recognize and respect my identity, my despair can lead me to forget who I am and I am condemned to follow the lifestyle dictated by my parent (dissociation). 
All these decisions made at that moment shape my future and constitute the quality of life I will lead. The more positive, enhanced and respectful such contact is, the more positive, enhanced and balanced contracts will be energetically synchronized.

Elena's prenatal context.

During pregnancy, mum wished for a boy child to please her husband. I don't like it. It's unfair. Why should she want a boy?

\section{Elena's contract.}

I will prove to her that I am better than a boy. I will assert. I will demand. I don't want to be in this mother's consciousness. But I will stay. And I will be strong. Because, how can I otherwise prove that I am better?

When I am born, there is such disappointment that I am a girl. I'll get revenge. I will show everybody that I am better than a man. And, I have done it! I am better than many men I know. I will fight for this. Nobody will offer this success. I'll use my power.

Elena suffers from hypertension. In her late fifties, she has earned a place in the academic world; many successful published books and high blood pressure.

\section{The Eye Contact that Makes a Difference}

At the moment of birth, when the first contact takes place on the physical plane through eye-to-eye contact - as Michel Odent mentions - there is another contract agreed that is to last for a lifetime - or when unbalanced, may lead to dysfunctional contacts throughout my life. This perinatal contact becomes the contract that is to dominate all relationships with people, business associates, friends, or intimate partners.

The first days/months, if mother and baby are together, contact and contract are OK. But, if they are separated - as it usually happens, e.g., newborns are kept in separate rooms, neonates may need emergency medical care or mother returns to work too early, then, the disturbance of contact may lead to a contract of loneliness that can last a lifetime.

\section{Gina's prenatal context.}

My mother does not want to have a baby. She thinks I am very ugly. (How ugly can a newborn be, I wonder?)

Gina's contract. Gina can't get pregnant.

My mum does not hug me; she doesn't feed me when I am hungry; she doesn't change my diaper. Mum is very tired. Dad never helps. I feel ugly, empty of love, lonely. I will try to find all I miss from other people; I have always felt my body is awful; I try to hide my ugliness because if they see that I am ugly they won't want me. If they don't like me, then I will be alone and being alone is what scares me. If I let people come close, they hurt me. So, I keep them at a distance; I change to fit to what the other wants me to be; I don't like it; I don't want to believe that it happened; I wish I could stop being so angry; I wish I could stop causing that pain to myself!

\section{Welcome and Thrive or Else Perish}

Would it be too risky if I thought of the many unfortunate cases when unwelcome conceptions or pregnancies take place during which the child and the mother join together in an environment of total or partial rejection or even an environment of ambivalence which ends up to a very poor quality of life, a punishment for all involved?

Fairytale images of inferno, of evil witches and evil stepmothers, of hot ovens ready to roast Hansel and Gretel and so on remind us of the instances of such contacts being equal to punishment. 
Sometimes, there are also decisions of overestimation - which is also another term that implies imbalance - either coming from the parent projecting the satisfaction of his need onto me the child or from me the impotent child overvaluing the power of my parent ending up with a lifetime that has lost harmony. I become either a prenatal therapist or "the hero" as C. G. Jung has described me or the impotent cripple. Joseph Campbell wrote The Hero with a Thousand Faces - the discovery of comparative mythology. Do my Prebirth contacts become my lifetime contracts realities or are they myths?

Every time I experience a positive or negative contract with myself, I prove what I believe I am.

When the contract is with others, I fulfil its content in any of these or all the following ways:

\begin{tabular}{|l|l|}
\hline Positive ways & Negative ways \\
\hline Fulfilling our destiny & Losing ourselves \\
Bringing balance to life & Exhausting ourselves \\
Creating & Even destroying ourselves \\
Developing & Being who they want us to be \\
Enhancing life & Protecting or saving others \\
True to myself & Obeying their wishes \\
\hline
\end{tabular}

When the contract is with the world, it may be a positive or enhancing contract, e.g., the world is a safe and empowering place to be. I can be creative and enjoy life. Or, if I believe the world is a negative or diminishing environment, e.g., the world is a threatening place to be. I spend all my life defending myself against the bad, diminishing, some may even say evil world and I may die before I live. Such contracts last for a lifetime unless changed or healed. The blessing is that Prebirth Psychology is a tool for such healing.

\section{Non-Genetic Influences that Stay and Stain}

Parents provide nongenetic contributions that dramatically influence the development of the offspring and have profound ecological and evolutionary implications. By influencing an organism's ability to adapt, they may influence the course of evolution (Pennisi, 1996). The non-genetic factors including prenatal environmental influences on the expression of Tourette's syndrome has been shown by S. S. Wolf et al. in 1996 for example. He says among others that "Maternal effects provide a powerful avenue for (altering) the course of the future by adding information content and material content. That content can be... anything that can influence how an embryo develops" (Wolf et al., 1996).

Anna. Anna is a young woman who came to the office in 2003 suffering from depression and nosophobia. Six months later, she felt much better and interrupted therapy. A couple of months later, she called to announce the news of her first pregnancy. She sounded rather numb on the phone. A few weeks later she asked for a session. When she came, she was 3 months pregnant. Her looked a mess; black bags under the eyes and much thinner than I remembered. She complained that she couldn't sleep at night. She is in fear that something is going to drown her. Her words: "There is a war going on. Who is going to win? Either the baby will kill me in my sleep, or I will win". Because of this war she had ceased to eat in her effort to beat the baby who she holds responsible for the drowning sensation. She hopes that the baby won't last and will die of hunger.

Working on that day, she realizes that her drowning sensation had nothing to do with the baby, but with her own unresolved issues with a boyfriend in the past; a relationship she had interrupted because she felt drowned. That was also a repetition of what she felt in her relationship with her father who obsessively controlled her. In her relationship with her father, she again had felt that drowning sensation. In her mind, at 
that moment of her pregnancy, there was one thought: "If I give birth to a boy, then we'll have to name him after my father-in-law. But, that was the name of my ex-boyfriend. I want to forget all about that relationship but having to use that name again, again, every day, it won't be easy. This thought drowns me. I don't want this child".

On that day she asked for orange juice and toasted bread to eat. She looked very relieved. She disappeared again. Half a year later, I received a call from her. She told me that she gave birth to a boy with cesarean in the 35th week of pregnancy. On her regular visit at her doctor, the doctor diagnosed that the sack was dry and on that same day she had the cesarean birth. The baby was born with tense muscles, griposis, refused to have any food, stayed at hospital for two months, where mother could visit him for only one hour a day. Mother didn't breastfeed him even for one day. She asked: "Is it because of that?" Today, the child is one year old and is still under medical supervision. And, he has already been diagnosed with mental retardation.

\section{Maternal Smoke and Other Toxic Stories}

Maternal toxins such as cigarette smoke, alcohol and drugs have a debilitating effect on the embryonic development and so does all chemical content of toxic nature. This is well known and recently very fervently investigated. When a pregnant mother smokes (active smoking) or when she is in an environment where others smoke (passive smoker) the unborn child is affected with lifelong consequences. We know that despite the well known averse consequences in pregnancy since 1972, many pregnant parents continue to smoke. We also know that even if only the father smokes and even if he is absent from home during the day or if he smokes out of the house (in the balcony) nicotine still remains in the tissues and influences the wife sharing the same bed at night. Women who are pregnant may also be exposed to secondhand smoke apart from homes, in vehicles, the workplace, or public areas. More than 126 million nonsmoking adults continue to be exposed to secondhand smoke and current estimates suggest that almost $60 \%$ of children, aged 3-11, are exposed to secondhand smoke (U.S. Department of Health and Human Services, 2006). Thus, exposure to cigarette smoke remains a common and hazardous in utero exposure. There are above 4,000 xenobiotics (foreign substances) found in cigarette smoke causing a lot of placenta challenges and even more for the unborn. The impact of such chemical intoxication is not restricted to the human body development but goes beyond that, affecting the emotional, mental functioning of the organism. Maternal smoking during pregnancy is a risk for abortion (Castles, Adams, Melvin, Kelsch, \& Boulton, 1999), preterm delivery (Castles et al., 1999; Kaddar et al., 2009; Shah \& Bracken, 2000), respiratory disease (Cook \& Strachan, 1999), immune system difficulties such as asthma and allergies (Prescott \& Clifton, 2009), and cancer later in life (Doherty, Grabowski, Hoffman, Ng, \& Zelikoff, 2009), alterations to the development and function of the placenta (Einarson \& Riordan, 2009), delayed psychomotor and mental developmental scores as measured by the Bayley Scales of Infant Development (Kiechl-Kohlendorfer et al., 2010), may negatively impact a child's future speech and language development (Benasich \& Tallal, 2002; Kable et al., 2009; Molfese, 2000), is responsible for physical aggression during early childhood (Huijbregts, Seguin, Zoccolillo, Boivin, \& Tremblay, 2007; 2008). Sudden Infant Death Syndrome (SIDS) is connected with parental smoking (Flemming \& Blair, 2015). According to the research, smoking "exposure may lead to a complex range of effects upon normal physiological and anatomical development in fetal and postnatal life that places infants at greatly increased risk of SIDS". What the researchers have also noted was the increase in maternal smoking from $50 \%$ to $80 \%$ among the population that presented SIDS. The question posed here, is what is the driving force behind this maternal behaviour? What is 
it that despite the public awareness concerning the harmful effects of parental smoking makes pregnant mothers smoke and endanger their babies? Other research has shown that "newborns and infants born to smoking mothers had higher arousal thresholds to auditory challenges than those born to nonsmoking mothers. The impact of exposure to cigarette smoke occurred before birth" (Franco Patricia et al., 1999). The hypoxia experience for the unborn child, associated with respiratory challenges (respiratory arrest) leads to a highly stressful primal experience that is to have lifelong effects for the baby postnatally—sleep apnea, brain or neurological disturbances, unusual facial characteristics, agitation, mental retardation, low stress tolerance, increased metabolic diseases risk, decreased cognitive functioning even death. Underweight births and prematurity are also among them with all the unpleasant consequences. With the advances in epigenetics, today, we are also aware of the epigenetic mechanisms that prenatal environmental factors like stress, prenatal drug exposure, etc., can lead to changes in gene expression (DNA methylation) from generation to generation with not only lifelong effects any more but generations long effects (Maccani \& Marsit, 2009). Suter and colleagues (2011) say that "maternal tobacco use is associated with aberrant placental epigenome-wide DNA and gene expression", with critical consequences for fetal development and postnatal health.

Associated with smoke and drug (cocaine, etc.,) abuse, today, there is another factor that needs to attract our attention. This refers to the use of anaesthesia or opiates used to alleviate pain during laboring. Maternal Methadone use is widely used and the research data today shows that it is responsible for the development of neonatal abstinence syndrome and it has serious implications for healthcare resources (Dryden, Young, Hepburn, \& Mactier, 2009).

Research in the field of prenatal psychology today has described Fetal programming connected with cigarette smoke or smoke/drugs in general.

\section{Smoking \& Fetal Programming}

Fetal Programming is the theory developed by Barker in 1980s and presents a model of "gene-environment interaction" that explains the influence of the in utero environment on the molecular character of development explaining that an adverse fetal environment (scarcity of nutrients, stress, viruses, drugs, trauma and smoking among them) may result in a negative or poor maternal forecast and a postnatal environment of scarcity. The baby is forecasted to thrive in a poor environment. Most of the stress for the unborn child - but also any human organism-arises from deprivation of the life essentials: oxygen and nutrients. The smoke captures the oxygen which is reduced when it reaches the baby through the placenta. This becomes a cause of stress for both the mother and the unborn. The heart rate increases and the organism tries to work out changes that will guarantee survival. This implies harder work on the part of the embryo who needs to support his own existence. The psychological pattern that arises here can be something like "I need to work hard to support somebody else who then can guarantee my survival" That is "I need to support the maternal organism because if the maternal organism cannot survive, I am lost as well". Furthermore, concerning the prematurity that is observed in such cases, we could interpret this stress faced by the unborn as an embryo language communicating "out of this environment the sooner the possible".

In psychological terms these seem to be the consequences:

(1) They reproduce the pattern "I need to work hard to maintain something of value". This shows in relationships. They stay in symbiotic relationship much longer than Nature has it (that is $4,41 / 2$ years of age). What later on happens is that they stay in partnerships (intimate or business) much longer than healthy 
"working hard to save and/or support the relationship or situation providing, resolving doing what it takes to make a relationship stay so they can survive";

(2) They present unresolved issues with the father;

(3) They have low stress tolerance;

(4) They present learning challenges, lower intellectual performance (Lundberg et al., 2009) and lower academic performance (D’Onofrio et al., 2010);

(5) They develop depression;

(6) They suffer from anxiety;

(7) They show ADHD (Knopik et al., 2010);

(8) They show conduct problems, or criminality traits (D’Onofrio et al., 2008);

(9) The situation is even worse when we replace cigarette smoking with drugs as the use of drugs implies even higher stress levels during the early primal experience that the born baby/adult wishes to get rid of.

Theodosia. Theodosia, a young lady in her early thirties is mother of one boy, she is not satisfied with her marriage, suffers from asthma. She records:

...Hugging, fondling, communication? I don't recall anything. I remember father more. Where is mum? Mum may have not wanted children. She may not have wanted me. I was the replacement of my sister who died 40 days after birth. Mum got crazy. I was born right afterwards as a replacement for Maria. I feel horrible. Why should I feel like I am a replacement? I'd rather she didn't give birth to me at all. She gave birth to me to cover up her own pain; to cover her void. Now, she looks after the boys. Mum, went through depression then. She used to talk and talk and talk to Maria. She sort of made me love her, too. I had never seen Maria. I couldn't share her pain. I myself try to be a replacement. And when the other person doesn't need me I leave. And, I feel betrayed. People take my support and whatever they need and then they pretend I don't even exist. They step out of the relationship. I may be a replacement for my husband too like when his mum abandoned him. I stay in the relationship because I don't want him to feel that I also desert him.

When pregnant, my mum smoked. And I asked her, "Why did you smoke? Didn't you know it was bad for me?" (Her mum was a midwife). She replied "After the labor", she said, "I asked my doctor for a cigarette". Before my birth, mum put me in danger. After birth at my 20th month, I was diagnosed with asthma.

During pregnancy: I feel I am in danger. I can't breathe. It's the cigarette. I need my mum not to smoke so that my little body can breathe freely in the womb.

I would like my mum to caress her belly so that I can feel she wants me; she loves me. I feel rejected because nothing happens to show me that she likes me. She wants me as a child but just to see me exist. I don't feel she is by me. She has never been near me. I'm always there to help her. I satisfy all she needs. I solve all her problems. I am there for her. She has never asked me if I have ever had any problems... I will get born, I will fill her void without thinking of myself... Who am I?... the 3 rd or the 4 th child?...

\section{Fetal Alcohol Syndrome \& Fasd}

The world-wide statistics for the fetal alcohol syndrome is 1.9 per 1,000 live births. Most of the parents that do alcohol abuse also do other substance abuse (caffeine, nicotine, diazepam etc.,) it goes without saying that the above mentioned unpleasant consequences associated with smoke are also to be observed when mother is on the drink or even worse when she is alcoholic. Although the ancient classics such as Plato and Aristotelis advise against alcohol at conception or pregnancy, and despite the Holy Bible saying "Behold, thou shalt conceive, and bear a son; and now drink no wine or strong drink... (Judges 13:7)" unfortunately the numbers are high. For centuries, there was a suspicion that alcohol was linked to teratogenesis and such evils but it was in the late 1960s when Lemoine started publishing the first research data on the understanding of the fetal alcohol syndrome and the ways ethanol affects human development. When pregnant mother drinks alcohol 
even small quantities - that is more than 1 glass of wine/week - this is experienced as "poison" by the unborn child. The sequence of this stressful primal experience leads to Primary and Secondary disabilities for the baby born. Among Primary disabilities we list brain damage, low academic capacities, learning disabilities, impaired mental functioning and low living skills, communication/socialization skills and adaptive behavior levels. The Secondary disabilities include Mental Health Problems, Disrupted School experience (high rates of drop out, suspension or expulsion), trouble with the law/criminality traits and violence, conduct misbehavior (high percentage of imprisonment), inappropriate sexual behavior, alcohol and drug problems themselves (perpetuation of the challenge), dependence (living), unemployment due to problems with employment and problems with parenting leading to more vicious cycles (Streissguth, Barr, Kogan, \& Bookstein, 1996), facial dysmorphology, central nervous system abnormality (Abel \& Sokol, 1986), neurodevelopmental disorders (Sampson et al., 1997).

Psychologically, the baby born later on:

(1) develops a negative self-image;

(2) a narcissistic personality emerges;

(3) There is over stimulation of the system which is associated with high degrees of anxiety or agitation;

(4) may present eating disorders;

(5) metabolic or cardiovascular disorders;

(6) or psychosis.

Apart from those the pattern that seems to emerge is that the person with FAS learns from very young to live on the minimum. The high toxicity levels reaching him through the placenta make him to lower his survival needs levels, the system gets contracted to protect the organism from the toxicity threat. This interprets into a human being who sees threats in the environment, or sees the environment as an enemy from which he either needs to isolate to survive or attack or resort to the prenatal survival mechanism of "the minimum is enough" and live a life of poverty or of minimum reward. This prenatal contact/contract is far from the stoic philosophers of minimizing the needs to develop virtues as it is not the result of spiritual evolution but the outcome of a traumatic experience retriggered and relived. From such a prenatal background, human relationships - both intimate and at work - are very challenging and a lot of healing support on many levels needs to be offered to bring the system back to balance before it makes way for a new generation to come and perpetuate the problem due to epigenetic changes.

Themis prenatal context. He is the fourth child in the family. He came many years after his brother and sisters at a time when mother expected to be free of the responsibilities of raising children and enjoy the comfort that a good financial condition could offer. Themis records:

My mum thinks that her reproductive cycle has come to an end. She doesn't want to be pregnant. She already has three kids. She doesn't want a fourth.

...I can hear it, I respect it but I want to survive. I'll get hold of my mum. She is going to have a good pregnancy. I will stay calm. I will go with her biological rhythm. I won't cause any sickness to her. I will get born very easily. I will be a boy so that she can have some balance among the kids (She had one son and two daughters already). Because I will be a boy she will have the chance to give me the name of her father which she wants. I won't have any behavior problems. I will eat my food, I won't be attached to her. I'll be independent as soon as possible so that I won't take up her time or energy and I will try to make her happy with my existence. I'll accept any replacement mother in practical issues. My sisters will help me with the food and clothes. I'll ask my brother and sisters about school questions. I'll even make mother proud. I'll be very good at public relations; the environment will accept me; I will be good at fixing things; I will be an excellent cook. And then he finishes by saying: "This is just to talk her into accepting me. If I could I'd like to run away 
from her; to get rid of her. Be independent, free. I don't want to be either the cause of sorrow or the cause of joy".

Themis contract. Themis says that he'd like to have three children: two girls and a boy. He also aborts a fourth child. Themis aborts himself: Themis is in his mid-forties, trying to get out of drugs. He lives in extreme poverty conditions, no friends, no partner, no children. However, the above is just a façade, a survival mechanism set prenatally to seduca the mother into not aborting him. But deeper there was fear and rage that was repressed. Some further analysis revealed this:

Themis shouts:

I'll fuck you all off. I'll give you a hell! I'll ignore you! I'll disappear. I'll push you too far to see where I can go and to see to which point you can put up with me. I'll break all relationships to show my powers.

This is very important to bear in mind. We may see happy faces in childhood and children that are the parent's joy. We may get tempted to jump into conclusions that the theoreticians and their conclusions as stated above are proven wrong. You need a very deep way of looking at things and distinguishing the phenomenon from the underlying causality, the mechanism from the underlying repressed trauma. This was also obvious in Marina's case, above.

\section{The Prenatal Origins of Disease}

A prenatal experience is always discovered behind a dysfunction or as an underlying cause of a disease (e.g., panic attacks, depression, cancer, blood pressure, addictions, phobias, etc.) triggered when similar circumstances to those prenatally re-appear postnatally. As mother provides the baby with both genes and prenatal environment, associations between prenatal risk factors and offspring disease maybe attributable to true prenatal risk effects or to the "confounding" effects of genetic liability that are shared by mother and offspring (Thapar Anita et al., 2007).

Dina's prenatal context. When Dina was conceived, her mother felt very unhappy. She didn't want to get married and have children. She was obliged to get married because her life conditions were so difficult. She was very poor and she already had a child. When pregnant for a second time (with Dina) her mother couldn't handle it. Being poor, unhappy and so exhausted; having already raised her younger child; and having to work to survive all the way through her pregnancy; no hospital to go to if needed; she thought of Dina-baby as a problem and wished for this child to die because she was nothing but an overwhelming problem.

Dina's contract. (in her own words) Dina suffers from depression.

I reject myself; I was born unworthy; people feel disgust when they meet me; they hate me; they use me. I have experienced indifference and lack of care; I have experienced severe beatings; and, from my birth on, I live in curses and hatred. I feel rejection; I feel hatred; I feel so miserable; my body shrinks; I suffer; I feel lonely; I think that I'll die; I am so much afraid; there is always an invisible threat to my life.

Ioulia. Ioulia is a young lady in her early thirties who suffers from anorexia nervosa. When we were working with her prenatal profile, it came out that she was a twin pregnancy. The other baby, a boy, didn't make it. She had accused herself of having all the food, preventing her brother from having any. She punished herself by depriving herself of food, after birth.

Note. In this case, the environment made things even worse. Mother, who didn't know that she was pregnant with twins, had a shock when at labor the second baby came out black and blue and died. Not forgiving herself for not protecting him, mother gave her living daughter two names; one for her and one for 
her twin brother; she made her study two different faculties; she pushed her to learn two foreign languages and two musical instruments. She asked her daughter to live two lives.

Mara was an unwanted birth. She was rarely held by the mother, who according to the recordings of the daughter, "Didn't want to be soiled or have her immaculate dresses destroyed by the baby". Nursing was allocated to nannies. When Mara was learning toilet habits, mother used to prick her buttocks to teach her the lesson. Mara's pain was so great that it was at that moment when she made the decision that she would never pass this pain to a child. Mara grew up. When entering puberty, a beautiful young lady by then, attracting the attention of males, she developed vaginal cancer and had a hysterectomy (to make sure that no babies will be born by her and suffer). Mara at the age of almost fifty entered therapy wondering why she used to pinch the little kids in the nursery school she directed.

\section{From Parent to Child: The Heritage that Locks or Evolves}

There is a thread that connects all people born in the familial tree. And we can trace certain patterns as they evolve within the environment (family, society, Humanity). The egg is the carrier of such transgenerational information as it links the history of all people born in the line holding and delivering the information from one generation to the next. Any unresolved traumas or issues travel down the history-or better say - the egg lane and are handed down to the next generation to deal with and hopefully to resolve and evolve. As epigenetics today show stress information can alter the DNA methylation and the distorted information/DNA/human genome can be delivered to the next generation or the humanity.

What is also known today is that mother or better say the maternal environment passes down to the fetus her own perceived attitudes about life. Mother's emotions (fear, anger, despair, guilt, but also joy, pleasure, etc.) are associated with biochemical alterations. As we live and experience our life in the world or with others in the world, we continuously respond emotionally and/or mentally to the environmental signals and we release such "signal" molecules into the blood, which by themselves activate receptors in answer to the stimuli provided. We could say, that the unborn child through this process gets a preview of the environment he is going to be born in later on and gets prepared for postnatal survival through behaviour "memories", "fetal programming" and fetal "filters". The unborn child learns life skills and relationships. The quality of such stimuli or prenatal education that the unborn receives determines the Quality of Life this person is going to enjoy postnatally. This passing on of information as Grigori Brekhman (2012) states in his Wave Theory is facilitated by the water molecules (almost $95 \%$ in the fetal body and $75 \%$ in the maternal body).

\section{Heal Thyself When There Is Still Time}

There is a triggering of any unresolved issues carried on by the pregnant parents from their own primal experience as soon as the conception of their child starts. And an opportunity for both generations- that making space for new life to emerge, and the baby emerging - to resolve, heal, develop and mature. Any healing support during pregnancy frees the future of the child allowing the child to reach his full potential.

Costas prenatal context. He is of Armenian Origin and the mother conceived at a historical time of political and social disturbances. Mother was pregnant with twins. When, she communicated the news of pregnancy to her partner - not married at the time, her partner fled the relationship abandoning the mother and the unborn children. The twin brother was born dead.

Costas' contract. Costas is a businessman who faces company problems feels deserted in his business chaos; deserted by his colleagues and helpers and deserted by his pregnant wife who stopped working in their 
joint enterprise. He says:

Mum herself deserted me. She allowed herself to be persuaded that she must get rid of these children (twin pregnancy) because father imposed that on her. And, for quite some time, she was persuaded that she didn't need the creatures she had in her. I can't live without her! When you are in such a phase of your life and you need the other person to live and the other person doesn't want you, you desert the other. The little fetus faces the fear that he won't survive. The fetus feels insecure.

(To the mother:) You cheated me. You deserted me. I feel angry and deeply sad for the rejection and the desertion that you didn't see clearly and you didn't do what you wanted.

(To the father:) You deserted me; not wanting my presence. He thinks it is not the right time. He avoids his responsibilities to support a child... I feel indifferent. Dad's rejection didn't unsettle me as much as mum's. Mum was pregnant, she had the power to decide.

Wait until I survive and then you'll see what I will do. I just wait for things to go on. When I am self-sufficient then I'll take the course of my life in my hands. Now I am not. I can't protect my life. A child is not an object that you can own and control.

(To the twin brother who didn't survive:) I thought you had deserted me too. Now, I know that you didn't cheat on me, but that you just chose to have control of your life. It was your right. Perhaps you knew better!

Costas re-experienced the same prenatal trauma when expecting his daughter. He experienced high levels of anxiety fearing for his wife and daughter loss (reliving the twin brother loss) and falling into the confusion of projecting (unconsciously) his promise to the twin brother on his daughter, seeing her as the coming of his brother.

We have the years between our birth and our time of us becoming parents to heal any unresolved issues connected with our own conception, gestation or birth so that we do not carry them on to our children when we become their parents. The same holds true of professionals like teachers, social workers, medicals, midwives, psychologists/psychotherapists... Human conception, gestation and birth is a sacred process that asks for professionals to have cleansed themselves from their pre/Perinatal issues. Special attention should be paid to healing the violence trauma inflicted on people born caesarean or those conceived IVF among others.

\section{Conflict of Interests?}

There is often a conflict of interests between pregnant parents and the unborn baby, esp. when there are unresolved issues at play. The professional who offers his support needs to be well experienced to distinguish, help balance and wisely guide. As our thoughts and acts matter, the stories exchanged in pregnant couple meetings can become poison to other pregnant couples. The person in charge of such prenatal groups needs to know a lot about group dynamics and have a huge experience to discover the hidden pre/Perinatal dynamics that can be at play in each environment. Also, to have the wisdom to discern any interest conflict based on unresolved issues.

Penelope. Penelope's mother was in love with one man but married another. When pregnant but not in love with her husband she didn't want the baby. She tried all recipes to abort; she even fell down the stairs. Despite the efforts, Penelope was born. Father used the baby to keep his wife in the marriage. Penelope suffers from kidney cancer and depression.

When mother was on the third month of her pregnancy, mum wanted to abort. She deliberately fell down the stairs. The environment in the womb is so unpleasant. Are you my mum? Why don't you hug me? Why don't you kiss me? Mum suffered from depression... My kidney looks like a fetus. It is curled up in fear. The fights in the house; my dad; why is he attacking me? He may not be able to put up with the depression of his wife. I feel so frightened. I can't scream. I can't make my existence known. I exist. I feel I'm a little rubbish... I hid my enthusiasm for life. I hid my appetite (She doesn't 
actually eat enough to survive). I hid my joy. I don't know what joy is any more. I was terrified. How can I face life? I swallowed the tears and they burn my throat. Mum said she didn't want the child. She asked dad to give her money for an abortion. Dad refused. If I wasn't born, I would be better off. It's this sadness that affected my kidney. I don't like being a nothing. Why didn't I react? I'm glad that I haven't given birth to any children.

\section{Bonding Starts Early}

Life is always there. It does not begin it does not end. It just is, changing forms but always registering information. We can't waste any time or the 9 months of pregnancy to welcome the baby born.

Bonding starts before conception and its quality is at play behind all and any relationship we establish with ourselves, others or the world and life. A high quality bonding is based on immediate response to the unborn baby's primal needs. Otherwise the baby feels lonely, neglected or abandoned, in despair, loses contact of his true identity, disconnected from his internal rhythm, etc., and a lot of healing work needs to be done to re-establish the balance lost.

\section{Stalo's prenatal context.}

I tried to come to my mother and father several times in the past, but they always sent me away. It was never the right moment. They sent me away through miscarriages. I felt bad because I should have known better and come at a more appropriate moment when they were ready to accept me. But, I insisted. I was in a hurry to experience life... I want to feel laughter, joy, air, play. I don't like mum's molding. She is not a good teacher. She doesn't teach me in a way I can understand. I want to learn through experience. I want to touch, to experience. This is the way I learn.

Stalo's contract. She is a divorced mother with one daughter. She experiences lots of emotional challenges.

\section{And Now What?}

We need to reflect what we do and what our motivation is behind our acts or research as academics. Although in the 19th and 20th centuries, science was the big voice, today we are to balance the Mind and the Heart supporting young professionals and Academics who have Feeling Minds and Thinking Hearts to progress and evolve even more, so that they can advance and share wisdom.

Besides, with the multicultural environments of present reality, professional education needs to encompass all cultures and ethic practices to promote understanding and co-existence.

We need to redesign our services to the society and implement community programs based on the new understanding so that the quality of life is guaranteed. Taking into account Salutogenic principles and modern complex theory we can conceive, design, implement and operate Primal Health Advancement Programs to work with the baby in the womb. During the next 50 years, we are called to resolve huge issues such as the energy challenge, pure water, food, environmental issues, poverty, terrorism and violence, disease, education, democracy, population. The answer to these challenges lies in the womb, or even better with the generation now living. How can we each contribute?

Healing is not forgiving our supposed enemies for the traumas they have inflicted on us. It has to do with understanding, acceptance, connecting with our essence and remembering who we are and why we are where we are.

But, most of all it has to do with appreciation for how enemies and friends have served us perfectly to grow, develop, mature and evolve- anelixis.

When this happens, the way of anelixis opens. The energy flows and life gets easier, brighter, more constructive and joyous leaving this trace on the World Non-Conscious for all other consciousness to benefit. 
The key is working with all people to become aware of their prebirth origins, trusting them and their processes of life and death. The psychologist, the medical doctor, the educator, the scientist, the researcher have a treasure in their hands which can help them understand the dynamics of disease and health, pain and joy, disaster and creation and, above, all learn about the wisdom of soul dynamics.

\section{That's Where Pre- \& Perinatal Psychology Can Help}

Expanding from the personal to the universal, as more and more of us make steps and heal ourselves, this healing energy impregnates the environment in which it appears and touches whoever is in this environment. As more and more people become awakened and remember, this can show the path for others to walk. Health Advancement Programs, educational modules, conscious parenting and therapeutic work can do miracles. As more and more of us realize the content of the principles of welcoming, acceptance, trust, respect, empowerment, support and love, the more we will contribute to agreeing contracts of unique harmony. Baby steps at the beginning can make giant strides in the end.

Exactly the way a musician can develop his theme and lead it to a triumphant crescendo, healing energy can be sent to conception, pregnancy and birth patterns accordingly, so that life can be supported and developed to its best to honor its existence and to bless human experience for all souls in process.

We can learn to approach the pregnant couple with no discrimination of any kind, look them in their soul eyes. We can join forces so that we can be present and hold hands with them as they heal their own pre-, periand after natal traumas; open up their consciousness and heart to welcome, respect, honor, recognize and appreciate the invaluable gift of new life as encountered in the prenate; looked at in the eyes of a baby at birth, seen in the acts of adults and releasing as it is present in the last breath at death.

\section{References}

Abel, E. L., \& Sokol, R. J. (1986). Fetal alcohol syndrome is now leading cause of mental retardation. Lancet, 2, 1222.

Abel Ernest, L., \& Sokol, R. J. (1987). Incidence of fetal alcohol syndrome and prevalence of alcohol-related anomalies. Drug and Alcohol Dependence, 19, 51-70.

Benasich, A. A., \& Tallal, P. (2002). Infant discrimination of rapid auditory cues predicts later language impairment. Behavioural Brain Research, 136(1), 31-49.

Brown, A. S., van Os, J., Driessens, C., Hoek, H. W., \& Susser, E. S. (2000). Further evidence of relation between prenatal famine and major affective disorder. Am. J. Psychiatry, 157, 190-195.

Brekhman, G. (2012). The man as a quantum-wave psychosomatic system. Medical Review, 4(1), 105-109. (in Serbia)

Campbell, J. (2004). The hero with a thousand faces. Princeton University Press.

Castles, A., Adams, E. K., Melvin, C. L., Kelsch, C., \& Boulton, M. L. (1999). Effects of smoking during pregnancy: Five meta-analyses. American Journal of Preventative Medicine, 16(3), 208-215.

Chamberlain, D. B. (1998). Prenatal receptivity and intelligence. J. Prenatal and Perinatal Psychology and Health, 12(3-4), 95-117.

Chamberlain, D. B. (1994). The sentient prenate: What every parent should know. Pre and Perinatal Journal, 9(1), 9-31.

Chamberlain, D. B. (1998). Babies remember birth (republished as "The mind of your new born baby"). North Atlantic Books.

Cook, D. G., \& Strachan, D. P. (1999). Health effects of passive smoking-10: Summary of effects of parental smoking on the respiratory health of children and implications for research. Thorax, 54(4), 357-366.

Czeizel, A. (2004). The primary prevention of birth defects: Multivitamins or folic acid? International Journal of Medical Sciences, 1(1), 50-61.

Doherty, S. P., Grabowski, J., Hoffman, C., Ng, S. P., \& Zelikoff, J. T. (2009). Early life insult from cigarette smoke may be predictive of chronic diseases later in life. Biomarkers, 14(Suppl. 1), 97-101.

D’Onofrio, B. M., Van Hulle, C. A., Waldman, I. D., Rodgers, J. L., Harden, K. P., Rathouz, P. J., \& Lahey, B. B. (2008). Smoking during pregnancy and offspring externalizing problems: An exploration of genetic and environmental confounds. Development and Psychopathology, 20(1), 139-164. 
D’Onofrio, B. M., Singh, A. L., Iliadou, A., Lambe, M., Hultman, C. M., Neiderhiser, J. M., Lichtenstein, P. A. (2010). Quasi-experimental study of maternal smoking during pregnancy and offspring academic achievement. Child Development, 81(1), 80-100.

Dowling, T. (2007). New parenting, psychotherapy, prenatal and perinatal care. Nutrition \& Health, 19(1-2), 81-84.

Dryden, C., Young, D., Hepburn, M., \& Mactier, H. (2009). Maternal methadone use in pregnancy: Factors associated with the development of neonatal abstinence syndrome and implications for 97 healthcare resources. BJOG: An International Journal of Obstetrics \& Gynaecology, 116(5), 665-671.

Einarson, A., \& Riordan, S. (2009). Smoking in pregnancy and lactation: A review of risks and cessation strategies. European Journal of Clinical Pharmacology, 65(4), 325-330.

Emerson, W. (1995). The vulnerable prenate. Paper presented at San Francisco APPPAH Congress, published in the Pre- and Perinatal Psychology Journal, 10(3), Spring 1996.

Gouni, O. (2004). The evolution of prenatal psychology. Textbook, cosmoanelixis.

Gouni, O. (2008). Prenatal cont(r)acts for a lifetime. Paper presentation at Parma ANEP Congress.

Ferenczi, S. (1929). The unwelcome child and his death instinct. Int. J. of Psychoanalysis, 10.

Fleming, P., \& Blair, P. S. (2015). Sudden infant death syndrome and parental smoking. Elsevier.

Franco, P., et al. (1999). Prenatal exposure to cigarette smoking is associated with a decrease in arousal in infants. The Journal of Pediatrics, 135(1), 34-38.

Fodor, N. (1949). Search for the beloved: A clinical investigation of the trauma of birth and prenatal condition. Hermitage Press.

Huijbregts, S. C., Seguin, J. R., Zoccolillo, M., Boivin, M., \& Tremblay, R. E. (2007). Associations of maternal prenatal smoking with early childhood physical aggression, hyperactivity-impulsivity, and their co-occurrence. Journal of Abnormal Child Psychology, 35(2), 203-215.

Heijmans, B. T., Elmar, W. T., ..., \& Lumey, L. H. (2008). Persistent epigenetic differences associated with prenatal exposure to famine in humans. PNAS Organization.

Huijbregts, S. C., Seguin, J. R., Zoccolillo, M., Boivin, M., \& Tremblay, R. E. (2008). Maternal prenatal smoking, parental antisocial behavior, and early childhood physical aggression. Development and Psychopathology, 20(2), 437-453.

Hibbeln, J. R., John, M. D., Colin, S., Pauline, E., Imogen, R., Cathy, W., \& Jean, G. (2007). Maternal seafood consumption in pregnancy and neurodevelopmental outcomes in childhood (ALSPAC study): An observational cohort study. The Lancet, $369(9561), 578-585$.

Janus, L. (1989). The hidden dimension of prenatal and perinatal experience in the works of Freud, Jung and Klein. International Journal of Prenatal and Perinatal Studies, 1, 51-65.

Kafkalides, A. (1980). The knowledge of the womb Corfu. Greece: Triklino House (English translation by Sandra Morris 1995. Heidelberg, Germany: Mattes Verlag).

Kable, J. A., Coles, C. D., Lynch, M. E., \& Carroll, J. (2009). The impact of maternal smoking on fast auditory brainstem responses. Neurotoxicology and Teratology, 31(4), 216-224.

Kaddar, T., Rouault, J. P., Chien, W. W., Chebel, A., Gadoux, M., Salles, G., Magaud, J. P. (2009). Two new miR-16 targets: Caprin-1 and HMGA1, proteins implicated in cell proliferation. Biology of the Cell, 101(9), 511-524.

Kendler, K. S., Karkowski, L. M., \& Prescott, C. A. (1999). Causal relationship between stressful life events and the onset of major depression. Am. J. Psychiatry, 156(6), 837-841.

Keverne, E. B. (1997). Genomic imprinting in the brain. Current Opinion in Neurobiology, 7, 463-468.

Kiechl-Kohlendorfer, U., Ralser, E., Pupp Peglow, U., Reiter, G., Griesmaier, E., \& Trawoger, R. (2010). Smoking in pregnancy: A risk factor for adverse neurodevelopmental outcome in preterm infants? Acta Paediatrica, 99(7), 1016-1019.

Knopik, V. S., McGeary, J. E., Nugent, N., Francazio, S., \& Heath, A. C. (2010). Smoking during pregnancy, maternal xenobiotic metabolism genes, and child externalizing behavior: A case-crossover design. Behavior Genetics, 201.

Knopik Valerie, et al. (2012). The epigenetics of maternal cigarette smoking during pregnancy and effects on child development. Dev. Psychopathol., 24(4), 1377-1390.

Lake, F. (2007). Clinical theology - A theological and psychiatric basis for clinical pastoral care. Lexington, KY: Emeth Press.

Lipton, B. H. (1998a). Nature, nurture and the power of love. Journal of Prenatal and Perinatal Psychology and Health, $13,3-10$.

Lundberg, F., Cnattingius, S., D’Onofrio, B., Altman, D., Lambe, M., Hultman, C., \& Iliadou, A. (2009). Maternal smoking during pregnancy and intellectual performance in young adult Swedish male offspring. Paediatrics and Perinatal Epidemiology, 24(1), 79-87. 
Maccani, M. A., \& Marsit, C. J. (2009). Epigenetics in the placenta. American Journal of Reproductive Immunology, 62(2), 78-89. Molfese, D. L. (2000). Predicting dyslexia at 8 years of age using neonatal brain responses. Brain and Language, 72(3), $238-245$.

Ney, P. G. (1983). A consideration of abortion survivors. Child Psychiatry and Human Development, 13(3), $168-179$. Republished Int. J. of Prenatal and Perinatal Psychology and Medicine, 10(1), 19-28.

Nijhout, H. F. (1990). Metaphors and the role of genes in development. Pubmed Bioessays, 12(9), 441-446.

Oikonomidou Chrisanthi et al. (2000/2013). Ethanol-induced apoptotic neurodegeneration and fetal alcohol syndrome. Science, 287, 1056-1060.

Pearce, J. C. (1992). Evolution's end: Claiming the potential of our intelligence. Harper.

Peerbolte, M. L. (1975). Psychic energy in prenatal dynamics: Introduction (p. XXXII). Servire B.V. Wassanaar NL.

Peerbolte, M. L. (1955). The orgastical experience of space and metapsychologic psychagogy: An outline of practical mental and social hygiene. Sijthoff.

Pennisi, E. (1996). A new look at maternal guidance. Science, 273, 1334-1336.

Prescott, S. L. (2011). The influence of early environmental exposures on immune development and subsequent risk of allergice disease. ALLERGY, 66, 4-6.

Prescott, S. L., \& Clifton, V. (2009). Asthma and pregnancy: Emerging evidence of epigenetic interactions "in utero"'. Current opinion in Allergy and Clinical Immunology, 9, 417-426.

Sampson, P. D. et al. (1997). Neurodevelopmental disorder. TERATOLOGY, 56, 317-326.

Shah, N. R., \& Bracken, M. B. (2000). A systematic review and meta-analysis of prospective studies on the association between maternal cigarette smoking and preterm delivery. American Journal of Obstetrics \& Gynecology, 182(2), 465-472.

Slotkin, T. A. et al. (1995). Loss of neonatal hypoxia tolerance after prenatal nicotine exposure: Implications for sudden infant death syndrome. Elsevier, Brain Research Bulletin, 38(1), 69-75.

Sonne, J. C. (1994a). The relevance of the dread of being aborted to models of therapy and models of the mind (Part I: Case examples). The International Journal of Prenatal and Perinatal Psychology and Medicine, 6(1), 67-86.

Sonne, J. C. (1994b). The relevance of the dread of being aborted to models of therapy and models of the mind (Part II: Mentation and communication in the unborn). The International Journal of Prenatal and Perinatal Psychology and Medicine, 6(2), 247-275.

Stein, Z., Susser, M., Saenger, G., \& Marolla, F. (1975). Famine and human development: The Dutch hunger winter of 1944-1945 (p. 284). New York, NY, US: Oxford University Press.

Streissguth, A. (2004). Risk factors for adverse life outcomes in fetal alcohol syndrome and fetal alcohol effects. Developmental and Behavioral Pediatrics, 25(4).

Streissguth, A., Barr, H., Kogan, J., \& Bookstein, F. (1996). Understanding the occurrence of secondary disabilities in clients with fetal alcohol syndrome (FAS) and fetal alcohol effects (FAE). Final Report: Centers for Disease Control and Prevention Grant No. R04/CCR008515.

Suter, M., Ma, J., Harris, A. S., Patterson, L., Brown, K. A., Shope, C., \& Aagaard-Tillery, K. M. (2011). Maternal tobacco use modestly alters correlated epigenome-wide placental DNA methylation and gene expression. Epigenetics, 6(11), 17819.

Thaler, D. S. (1994). The evolution of genetic intelligence. Science, 264, 224-225.

Thapar, A., et al. (2007). Do intrauterine or genetic influences explain the foetal origins of chronic disease? A novel experimental method for disentangling effects. BMC Medical Research Methodology, 7, 25.

Turner, J. R., \& TGN. (1992). Discovering the emotional DNA: The emotional continuity for the unborn child through prebirth memory therapy. The 10th ISPPM International Congress Cracow, Poland, May 15-17.

Turner, J. R., \& TGN. (1993). Prebirth memory therapy including prematurely delivered patients. Pre and Perinatal Psychology Journal, 7(\#4 Summer), 321-332.

Turner, J. R. G. \& Turner-Groot TGN. (1994). La therapia della memory prenatale. Educazione Prenatale Italy, 1(3), 5-11.

Turner, J. R. (1988). Birth, life and more life: Reactive patterning based on prebirth events (Chap. 27, pp. 309-316, Prenatal and perinatal psychology and medicine: Encounter with the unborn editors). Parthenon Publ. NJ: Peter G. Fedor-Freybergh \& ML Vanessa Vogel.

Verny, T. R. (1981). The secret life of the unborn child. New York, Bantam Press.

Verny, T. R., \& Pamela, W. (2003). Pre-parenting: Nurturing your child from conception (Tomorrow's baby previous title). N.York: Simon \& Schuster.

Wal, van der J. (2011). The speech of the embryo. Retrieved from http://www.embryo.nl/ 
Walker, S. P., Theodore, D. W., Sally, G. -M., Maureen, M. B., Charles, A. N., \& Sandra, L. H. (2011). Inequality in early childhood: Risk and protective factors for early child development. Lancet, 378, 1325-1338.

Wolf, S. S. et al. (1996). Tourette syndrome: Prediction of phenotypic variation in monozygotic twins by caudate nucleus D2 receptor binding. Science, 273, 1225-1227.

Wynn, A. H. A., Crawford, M. A., Doyle, W., \& Wynn, S. W. (1991). Nutrition of women in anticipation of pregnancy. Nutr. Health, 7, 69-88.

Zweig, S. (1922). The eyes of my brother (Original title: Die Augen des ewigen Bruders). Forever. 